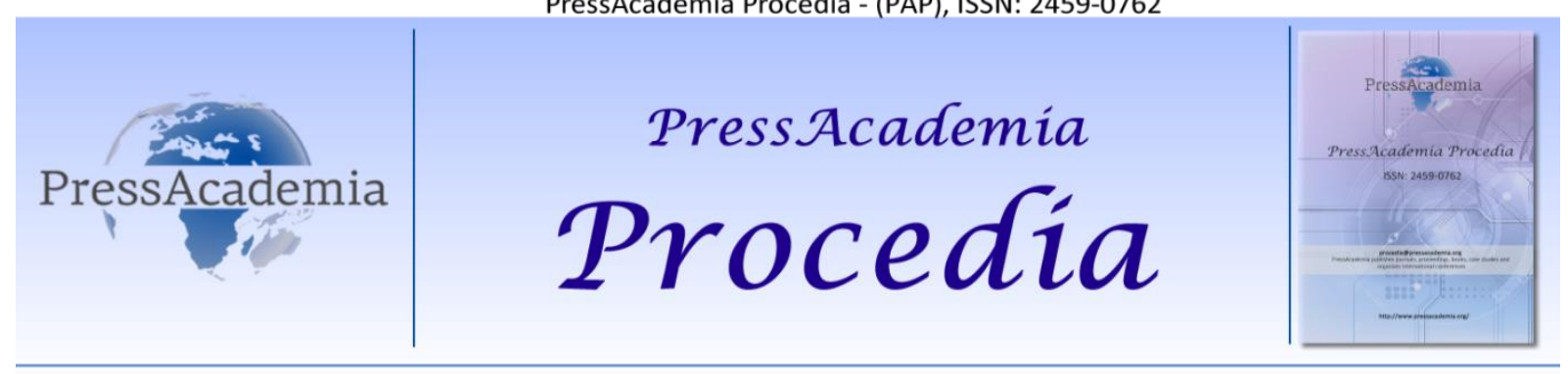

Global Business Research Congress (GBRC), May 24-25, 2017, Istanbul, Turkey

\title{
DETERMINATION OF THE LEVEL OF COMMUNICATION SKILLS OF EMPLOYEES IN THE BANKING SECTOR
}

\author{
DOI: 10.17261/Pressacademia.2017.628 \\ PAP- GBRC-V.3-2017(54)-p.533-540
}

\author{
Ismail Atabay ${ }^{1}$, Bayram Alamur ${ }^{2}$, Mustafa Melkin Oder ${ }^{3}$ \\ ${ }^{1}$ Balıkesir University. atabay@balikesir.edu.tr \\ ${ }^{2}$ Balıkesir University. bayramalamur@balikesir.edu.tr \\ ${ }^{3}$ Balıkesir University. mstfoder@gmail.com
}

\section{To cite this document}

Atabey, I., B. Alamur and M. M. Oder, (2017) Determination of the level of communication skills of employees in the banking sector. PressAcademia Procedia (PAP), V.3, p.533-540.

Permanent link to this document: http://doi.org/10.17261/Pressacademia.2017.628

Copyright: Published by PressAcademia and limited licenced re-use rights only

\begin{abstract}
Communication is transfer, notification, correspondence of feelings, thoughts or knowledge to others in any way that may come to mind. Communication skills can be summarized as the form of sensitivity to verbal and non-verbal messages, effective listening, and effective response. Communication skills are very important, especially in the sense of understanding others and gaining sensitivity to seeing their feelings and thoughts by identifying with them. The issues that are gaining importance in the work environment are how the individuals form a relationship and communicate with one another as well as the need for having them possessing the professional knowledge and skills. Though communication skills are of particular importance in all occupational groups, it is more important in professions where people are in intensive communication. In the banking sector, which is part of the service sector, the communication skills of employees are extremely important because of the intensive communication with the people. Thus, the purpose of this research, is to determine the level of communication skills of the employees in the banking sector. In the implementation stage of this research face-to-face surveys were conducted with employees in the banks that are active in Edremit Bay region (including Edremit, Burhaniye, Gömeç, Ayvalık, Havran) of Balıkesir province. To determine communication skills The Communication Skills Inventory (IBE) which was developed by Ersanlı and Balcı (1998) was used. SPSS statistical package program was used for the analyses. As a result of the analyses, various suggestions have been made to practitioners and academicians.
\end{abstract}

Keywords: Banking sector, communication, communication skills, service industry, banking employee JEL Codes: M30, M31, L82

\section{BANKACILIK SEKTÖRÜNDE ÇALIŞANLARIN ILETIŞIM BECERILERI DÜZEYININ TESPITi}

\section{ÖZET}

İletişim; duygu, düşünce veya bilgilerin akla gelebilecek her türlü yolla başkalarına aktarılması, bildirim, haberleşme ve komünikasyondur. İletişim becerileri sözel olan ve olmayan mesajlara duyarlılık, etkili olarak dinleme ve etkili olarak tepki verme biçiminde özetlenebilir. İletişim becerileri, özellikle başkalarını anlamada, onların duygu ve düşüncelerini onlarla özdeşleşerek görme duyarlılı̆ı kazanmada çok önemlidir. Çalışma hayatında sadece kişinin hangi mesleki bilgi ve becerilere sahip olması gerektiğinin yanı sıra birbirleriyle nasıl ilişki kurdukları ve nasıl anlaştıkları konuları da önem kazanmaktadır. İletişim becerisi, tüm meslek gruplarında belli düzeyde gerekmekle beraber, insanlarla yoğun iletişimde bulunulan mesleklerde çok daha önemlidir. Hizmet sektöründe yer alan bankacılık sektöründe de insanlarla yoğun iletişim gerektiğinden, çalışanların iletişim becerileri son derece önemlidir. Buradan hareketle bu araştırmanın amacı, bankacılık sektöründe çalışanların iletişim beceri düzeylerini belirlemektir. Bu araştırmanın uygulama aşamasında Balıkesir ili Edremit Körfezi bölgesinde (Edremit, Burhaniye, Gömeç, Ayvalık, Havran) faaliyet gösteren bankalardaki çalışanlarla yüzyüze anket çalışması yapılmıştır. İletişim beceri düzeylerinin tespitine yönelik olarak Ersanlı ve Balcı (1998) tarafından geliştirilmiş İletişim Becerileri Envanteri (IBE) kullanılmıştır. Analizler için SPSS istatistik paket programı kullanılmıştır. Analizler sonucunda uygulayıcılara ve akademisyenlere çeşitli öneriler getirilmiştir.

Anahtar Kelimeler: Bankacılık sektörü, iletişim, iletişim becerileri, hizmet sektörü, bankacılık çalışanı JEL Kodları: D23, G21, 014 


\section{GiRiş}

Dünya üzerinde ekonomik sistemlerin gelişmesi ve finans hareketlerinin serbestlik kazanmasının ardından bu alanda etkin bir rol oynayan bankaların ve bankacılık sektörünün önemi gittikçe artmıştır. Banka kavramı, Türkçe karşılığı masa, sıra veya tezgâh anlamına gelen İtalyanca "Banco" deyiminden gelmektedir (Akgüç, 1992:7). Literatürde banka ve bankacık sektörü ile ilgili birçok tanımlama yapılmaya çalışıldığı görülmektedir. Şendoğdu (2006) bankayı, sermaye, para ve kredi konularına giren her türlü işlemleri yapan ve düzenleyen kamusal ve özel kişilerle, işletmenin bu alandaki her türlü ihtiyaçlarını karşılama faaliyetlerini esas çalışma konusu olarak seçen bir ekonomik birim olarak tanımlamıştır. En gelişmiş tanımıyla banka, mevduat kabul eden, bu mevduatı en verimli şekilde çeşitli kredi işletmelerinde kullanmak amacı güden veya kısaca; faaliyetlerinin esas konusu düzenli bir şekilde kredi almak ve kredi vermek olan bir ekonomik kuruluş olarak ifade edilebilir(Altuğ, 2000: 3). Ancak günümüzdeki bankalar öyle çok çeşitli konularda faaliyet göstermektedirler ki, bugünkü özelliklerinin tamamını kapsayan genel bir tanım vermek oldukça güçtür (Eyüpgiller, 2000: 22). Bankalar günümüzde ekonominin temel aktörlerinden biri olduğu kadar, devletlerin iktisat politikalarının etkinliğinin arttırılmasında da önemli bir görev üstlenmektedirler. Bankacılık sektörünün bu artan ve gelişen önemi, sektörde birden fazla bankanın faaliyette bulunmasını sonucunu doğurmuştur. Önceleri daha az sayıda ve ölçeklerde bankalardan bahsedilirken, günümüzde zaman zaman küresel boyutlarda faaliyet gösteren bankaların da yer aldığı çok sayıda banka işletmesi sayılabilmektedir. Bankacılık faaliyetlerinin başladığı ve sürdüğü ilk zamanlarda klasik bir şekilde, belirli zaman ve mekânlar içinde faaliyet gösteren bankalar, ilerleyen zamanlarda teknolojik gelişmelerin de katkısıyla mekan ve zaman kısıtlarını büyük ölçüde aşarak faaliyetlerini sürdürmektedirler. Teknolojik yenilenmenin bankacılık sektöründe de kendine yer bulmasına ve insan gücüne duyulan ihtiyacın giderek azalmasına karşın, sektörün çalışan işgücüne katkısı önemli boyutlara ulaştığı görülebilir.

Mayıs 2017 itibariyle ülkemizde 3 kamu sermayeli, 9 özel sermayeli, 21 yabancı sermayeli 13 kalkınma ve yatırım ve 5 katılım bankası olmak üzere toplamda 51 banka faaliyet göstermektedir. 2016 yıl sonu baz alındığında, 10.781 şubede toplam 196.699 banka çalışanı sektörde hizmet sunmakadır. Rakamlar, sektörün büyüklüğünü ve ulusal ve küresel bir rekabetin varlığını göz önüne sermektedir. Yapısı gereği hareketli ve stresli bir ortama sahip bankalarda iletişim becerileri gibi örgütsel davranış konuları çalışandan sağlanan verimin artırılması noktasında ayrıca önem arz etmektedir. Bankacılık sektöründe çalışanların, sektördeki konumları, çalıştıkları bankalar bazında değişiklik gösterse de mesleki bilgileri kadar önemli ölçüde iletişim ve iletişim becerilerinin de ön plana çıktığı izlenebilir. Bankacılık mesleği, yapısı gereği insan ilişkilerinin ve iletişim gerekliliğinin üst düzeyde arandığı bir sektör olarak karşımıza çıkmaktadır. Literatürde farklı şekillerde tanImlanan iletişim; etimolojik olarak Latince'de ortak anlamına gelen "communis" ve "ortak kılma" anlamına gelen "communicare" sözcüklerinden türemiş İngilizce "communication" kavramının karşılığıdır(Gürgen, 1997: 11). illetişim ile ilgili çeşitli tanımlamalar yapılmıştır. Illetişim, istenen sonuçları başarmak ve davranışları etkilemek amacıyla insanlar arasında sözlü ya da sözlü olmayan diğer araçlarla anlayış sağlamadır (Can, 1999: 254). liletişim, bireyin birtakım semboller kullanarak karşısındakini etkileme süreci olarak da tanımlanabilir(Dökmen, 1994: 10). Iletişim birbirlerine ortamdaki nesneler, olaylar, olgularla ilgili değişmeleri haber veren, bunlara ilişkin bilgilerini birbirine aktaran, aynı olgular, nesneler, sorunlar karşısında benzer yaşam deneyimlerinden kaynaklanan, benzer duygular taşıyıp bunları birbirine ifade eden insanların oluşturduğu topluluk ya da toplum yaşamı içinde gerçekleştirilen tutum, yargı, düşünce ve duygu bildirişimleridir(Oskay, 2001: 9).

Yapılan tanımlamalardan anlaşılacağı üzere iletişim, insanların birbirini anlamalarının ilk adımı olarak görülebilir. Özellikle insanlarla daha çok bir arada olmayı gerektiren meslek alanlarında çalışanların iletişim becerilerine daha fazla hâkim olmaları gerekmektedir (Korkut, 2005, 143). Bu açıdan bankacılık sektöründe de iletişim ve çalışanların iletişim becerileri, onlardan beklenen işletme içi başarının artması açısından önemli bir yer tutmaktadır. Gökçe vd. (2001) başarılı bir iletişim için, bireylerin iletişim şartlarını bilmesi gerektiğini, bireylerin sosyal olabilmesi için etkileşimde bulunmaları ve sürekli olarak iletişim yeteneklerini geliştirmeleri gerektiğini ve dolayısıyla da sosyalleşmenin iletişim yeteneğiyle ilgili olduğunu vurgulamaktadırlar. Çağımızın iş dünyasında yaşanmakta olan değişimlerle birlikte, yeni yaklaşımlar ve yeni bakış açıları ortaya çıkmakta, çalışan bireyden beklenenler, başarı ölçütleri ve çalışma düzeni bunlardan etkilenmektedir(Erigüç vd., 2013: 46). Bankacılık sektöründe çalışanların, her ne kadar teknolojiyi yoğun olarak kullandıkları görülse de gerek ticari hayat gerekse bireylerin finansal işlemleri açısından, iletişime ve bu alandaki becerilerini geliştirmeye ihtiyaç duyacakları açıkça görülebilir. Etkili iletişim becerileri, her türlü insan ilişkisinde ve her türlü meslek alanında ilişkileri kolaylaştıııcı olabilmektedir(Korkut, 2005:143). İletişim becerilerinin iş hayatındaki önemi ile ilgili farklı sektörlere yönelik olarak çeşitli çalışmalar yapılmıştır. Literatürde, genel olarak iş hayatına(Keenan ve Brady, 2002; Taylor, 2000), sağlık sektörüne ve özellikle çalışanlardan hemşirelere (Dickson, 1989; Sellick 1991), güvenlik güçlerine(Bauer, 1989), öğretmen ve öğretmen adaylarına (Uğurlu, 2013; Saraçoğlu vd., 2009; Çam, 1999) yönelik çalışmalarda bulunulmuştur.

\section{ARAŞTIRMA}

\subsection{Araştırmanın Amacı}

Bu araştırmanın amacı, bankacılık sektöründe çalışanların iletişim beceri düzeylerini belirlemek ve demografik faktörlere göre farklılık gösterip göstermediğini tespit etmektir. 


\subsection{Araştırmanın Sınırlılıkları}

Bu araştırma Balıkesir ili Edremit Körfezi bölgesinde (Edremit, Burhaniye, Gömeç, Ayvalık, Havran) faaliyet gösteren bankalardaki çalışanlar üzerinde yapılmış olup, farklı sektörlerde çalışanların ve ülkemizin diğer bölgelerinde faaliyet gösteren banka çalışanlarının zaman ve imkânlar nedeniyle araştırmaya dâhil edilememiş olması bu araştırmanın kısıtlarını oluşturmaktadır.

\subsection{Araştırmanın Örneklemi}

Balıkesir ili Körfez bölgesinde (Edremit, Burhaniye, Gömeç, Ayvalık, Havran) faaliyet gösteren banka çalışanları bu araştırmanın ana kitlesini oluşturmaktadır. Balıkesir ili Körfez bölgesinde (Edremit, Burhaniye, Gömeç, Ayvalık, Havran) 53 ulusal banka şubesi bulunmaktadır. Kolayda örnekleme yöntemiyle seçilen ve araştırmaya katılmayı kabul eden 240 çalışan araştırmanın örneklemini oluşturmuş ve bu anketlerden eksiklikleri bulunmayan 224 adeti kullanılmıştır.

\subsection{Araştırmada Kullanılan Veri Toplama Araçları ve Verilerin Analizi}

Araştırmada; Ersanlı ve Balcı (1998) tarafından geliştirilen 45 maddeden oluşan "iletişim Becerileri Envanteri” ve kişisel bilgi formu kullanılmıştır.

Ölçek zihinsel, duyuşsal ve davranışsal olmak üzere üç alt boyuttan oluşmaktadır. Her bir boyutu ölçen 15 madde vardır. Her alt boyut ayrı ayrı değerlendirileceği gibi ölçeğin toplamına bakarak bireyin genel iletişim beceri düzeyi de belirlenebilir. Hangi alt ölçekteki puanı yüksek ise iletişim becerisi açısından bireyin o alt boyutta daha iyi olduğu söylenebilir. Ölçeğin tamamı için ise puanların yüksekliği o bireyin iletişim beceri düzeyinin yüksek olduğunu göstermektedir (Ersanlı, Balcı 1998).

“iletişim Becerileri Envanterindeki” ifadelerden her biri; (1) Kesinlikle Katılmıyorum , (2) Kısmen Katılmıyorum, (3) Emin Değilim, (4) Kısmen Katılıyorum, (5) Kesinlikle Katılıyorum olmak üzere 5 basamaklı Likert tipi puanlanmıştır.

Kişisel bilgi formunda ise banka çalışanlarının demografik özelliklerine yönelik sorular yer almaktadır. Verilerin analizinde SPSS 22 istatistik paket programı kullanılmıştır.

\section{Araştırma Bulguları ve Verilerin Analizi}

\subsection{Demografik Faktörlere ilişkin Bulgular}

Aşağıdaki Tablo-1'de ankete katılan bankac çalışanlarının demografik özelliklerini gösteren frekans dağılımları görülmektedir.

Tablo 1: Cevaplayıcıların Demografik Özelliklerine İlişkin Değerler

\begin{tabular}{|l|c|c|}
\hline Cinsiyet & Frekans & Yüzde \\
\hline Kadın & 83 & 37,1 \\
\hline Erkek & 141 & 62,9 \\
\hline Toplam & 224 & 100,0 \\
\hline Medeni Durum & Frekans & Yüzde \\
\hline Evli & 139 & 62,1 \\
\hline Bekar & 85 & 37,9 \\
\hline Toplam & 224 & 100,0 \\
\hline Meslekte Toplam Süre & Frekans & Yüzde \\
\hline $1-5$ yıl & 98 & 43,8 \\
\hline $6-10$ yıl & 84 & 37,5 \\
\hline $11-15$ yıl & 22 & 9,8 \\
\hline $16-20$ yıl & 17 & 7,6 \\
\hline 21 yıl ve üzeri & 3 & 1,3 \\
\hline Toplam & 224 & 100,0 \\
\hline Çalışılan Pozisyon & Frekans & Yüzde \\
\hline Bireysel & 46 & 20,5 \\
\hline Güvenlik & 23 & 10,3 \\
\hline Müdür & 12 & 5,4 \\
\hline Operasyon & 80 & 35,7 \\
\hline Ticari & 38 & 17,0 \\
\hline Yan Hizmetler & 25 & 11,2 \\
\hline Toplam & 224 & 100,0 \\
\hline
\end{tabular}

\begin{tabular}{|l|c|c|}
\hline Yaş & Frekans & Yüzde \\
\hline 25 yaş ve altı & 29 & 12,9 \\
\hline $26-30$ yaş & 60 & 26,8 \\
\hline $31-35$ yaş & 65 & 29,0 \\
\hline $36-40$ yaş & 38 & 17,0 \\
\hline $41-45$ yaş & 21 & 9,4 \\
\hline 46 yaş ve üzeri & 11 & 4,9 \\
\hline Toplam & 224 & 100,0 \\
\hline Şu anki İşyerinde Toplam Süre & Frekans & Yüzde \\
\hline $1-5$ yıl & & \\
\hline $6-10$ yıl & & \\
\hline $11-15$ yıl & & \\
\hline $16-20$ yıl & & \\
\hline 21 yıl ve üzeri & & \\
\hline Toplam & & 100,0 \\
\hline Ëgitim & Frekans & Yüzde \\
\hline illköğretim & 10 & 4,5 \\
\hline Lise & 49 & 21,4 \\
\hline Üniversite & 155 & 69,2 \\
\hline Yüksek Lisans & 9 & 4,0 \\
\hline Doktora & 1 &, 4 \\
\hline Toplam & 224 & 100,0 \\
\hline Gelir & Frekans & Yüzde \\
\hline $1.800 T L$ ve Altı & 66 & 29,5 \\
\hline & & \\
\hline
\end{tabular}




\begin{tabular}{|l|c|c|}
\hline $1.801 \mathrm{TL}-2.500 \mathrm{TL}$ & 61 & 27,2 \\
\hline $2.501 \mathrm{TL}-3.500 \mathrm{TL}$ & 55 & 24,6 \\
\hline $3.501 \mathrm{TL}-4.500 \mathrm{TL}$ & 25 & 11,2 \\
\hline $4.501 \mathrm{TL}$ ve Üzeri & 17 & 7,6 \\
\hline Toplam & 224 & 100,0 \\
\hline
\end{tabular}

\subsection{Faktör Analizleri ve Güvenilirlik Testleri}

İletişim Becerileri Envanterine ilişkin olarak yapılan faktör analizinin ve güvenilirlik testlerinin sonuçları Tablo-2'de yer almaktadır. Yapılan açıklayıcı faktör analizi sonucunda, 45 ifadeden oluşan İletişim Becerileri Envanterinden, ölçek yapısını bozan 10 soru çıkarılmış ve orijinal çalışma ile uyumlu 3 faktör elde edilmiştir. Ölçekten çıkarılan sorular Tablo-3'de verilmiştir.

Yapılan güvenilirlik analizi sonuçları incelendiğinde iletişim becerileri ölçeğindeki tüm boyutların güvenilirlik katsayısının 0,70'i geçtiği görülmüştür. Bu nedenle kullanılan ölçeğin güvenilir olduğu söylenebilir (Büyüköztürk, 2012).

Tablo 2: İletişim Becerileri Ölçeğine illişkin Açıklayıcı Faktör ve Güvenilirlik Analizi Sonuçları

\begin{tabular}{|c|c|c|}
\hline Faktörler & $\begin{array}{c}\text { Faktör } \\
\text { Yükü }\end{array}$ & $\begin{array}{c}\text { Cronbach's } \\
\text { Alpha }\end{array}$ \\
\hline \multicolumn{3}{|l|}{ Faktör-1 Zihinsel i̇letişim Becerileri (ZiB) } \\
\hline 6. Dikkatimi karşımdakinin ilgi alanı üzerinde toplayabilirim. & ,939 & \multirow{12}{*}{,979 } \\
\hline 28. Başkalarını dinlemek mecburiyetinde olmadığımı düşünürüm. & ,931 & \\
\hline 43. Öneride bulunduğun kişinin öneriye açık olup olmadığına dikkat ederim. & ,921 & \\
\hline 17. Karşımdakinin konuşmaya ve dinlemeye istekli olup olmadığını anlamaya çalışırım. & ,916 & \\
\hline 20. Anlaşılmazsam, yeni kelimelerle tekrar ifade eder, özetlerim. & ,913 & \\
\hline 24. Karşımdaki kişinin bana ters düşen duygu ve düşüncelerini eleştiririm. & ,908 & \\
\hline 12. Eleştirilerimi karşımdaki kişiyi incitmeden iletirim. & ,904 & \\
\hline 45. Kendimi karşımdakinin yerine koyarak, duygu ve düşüncelerini anlamaya çalışırım. & ,873 & \\
\hline 03. Düşüncelerimi başkalarına tam olarak iletmekte zorluk çekerim. &, 872 & \\
\hline 30. Tartışmada, savunduğum düşüncelerin yanlış olduğunu kabul edebilirim. &, 869 & \\
\hline 18. Yanlış tutum ve davranışlarımı kolaylıkla kabul ederim. & ,867 & \\
\hline 15. Karşımdaki kişiyle aynı görüşü paylaşmasam bile fikirlerine saygı duyarım. & ,863 & \\
\hline \multicolumn{3}{|l|}{ Faktör-2 Davranışsal İletişim Becerileri (DAB) } \\
\hline 32. İnsanları kontrol etmeye ve istediğim kalıba sokmaya çalışırım. &, 873 & \multirow{12}{*}{,727 } \\
\hline 41. İnsanlara cevaplamada zorlanacakları ani sorular yöneltirim. & ,823 & \\
\hline 21. İnsanlarla görüşürken, konuşmada onları rahatlatacak şeyler söylerim. &, 810 & \\
\hline 14. Konuşurken açık, sade ve düzgün cümleler kurarım. & ,808 & \\
\hline 23. Küs olduğum birisiyle barışmak istediğimde ilk adımı atmaktan çekinirim. & ,786 & \\
\hline 22. Dinlerken, karşımdaki kişinin sözünü kesmemeye özen gösteririm. & ,775 & \\
\hline 13. Konuşurken ilk adımı atmaktan çekinmem. & ,765 & \\
\hline 16. İletişimde bulunduğum kişinin yüzüne baktığım halde sözlerini dinlemediğim olur. & ,705 & \\
\hline 25. Ses tonumu konunun özelliğine göre ayarlayabilirim. &, 635 & \\
\hline 02. İletişimde bulunduğum insanlardan gelen önerileri içtenlikle dinlerim. &, 628 & \\
\hline 19. Dinlediğim kişiyi daha iyi anlamak için sorular yöneltirim. &, 624 & \\
\hline 10. Başkaları konuşurken sabırsızlanır, onların sözünü keserim. & ,456 & \\
\hline \multicolumn{3}{|l|}{ Faktör-3 Duygusal İletişim Becerileri (DUB) } \\
\hline 35. Çoğunlukla duygularımdan emin olamıyorum. & ,875 & \multirow{11}{*}{,929 } \\
\hline 34. Çevremdeki insanlara karşı ilgisiz kaldığım olur. & 841 & \\
\hline 11. İnsanları dinlerken sıkıldığımı hissederim. & ,831 & \\
\hline 44. İletişim kurduğum insanlar tarafından anlaşıldığımı hissederim. & ,819 & \\
\hline 40. İletişim kurduğum kimselerle bilgi alışverişinde bulunurum. & ,813 & \\
\hline 38. Karşımdaki kişiye güvenmek beni mutlu eder. &, 800 & \\
\hline 27. Karşı cinsten biriyle iletişim kurduğumda rahatsızıı duyarım. & ,774 & \\
\hline 29. Özür dilemek bana zor gelir. & ,770 & \\
\hline 09. Karşımdaki kişiyi dinlerken hayal kurarım. & ,713 & \\
\hline 05. Genelde eleştirilmekten hoşlanmam. &, 629 & \\
\hline 42. Beni rahatsız eden duygularımı iletmekte sıkıntı çekerim. &, 556 & \\
\hline
\end{tabular}


Çıkarım Metodu: Principal Component Analysis.

Döndürme Metodu: VarimaxwithKaiserNormalization

Keiser-Meyer-OlkinMeasure of SamplingAdequacy : , 874

Açıklanan toplam varyans: 65,823

Toplam Cronbach's Alpha : ,889

Tablo 3: Iletişim Becerileri Envanterinden Çıkarılan Sorular

\begin{tabular}{|c|l|}
\hline Madde No & ifade \\
\hline 1 & İnsanları anlamaya çalışırım. \\
\hline 4 & Konuşurken, etkili bir göz iletişimi kurabilirim. \\
\hline 7 & Kişilerin, anlattıklarını dinlerken yeterince zaman ayırııım. \\
\hline 8 & Karşımdaki kişiye genellikle söz hakkı veririm. \\
\hline 26 & Genellikle insanlara güvenirim. \\
\hline 31 & Konuşurken sözümün kesilmesinden rahatsız olurum. \\
\hline 33 & İletişim kurduğum kişinin tutumundan daha çok, sorununu anlamaya çalışırım. \\
\hline 36 & iletişim kurduğum kimse tarafından anlaşılmak beni mutlu eder. \\
\hline 37 & Karşımdaki kişiye güvenmek beni mutlu eder. \\
\hline 39 & Her insanı olumlu beklentilerle karşılarım. \\
\hline
\end{tabular}

Ankete katılan banka çalışanlarının iletişim becerileri envanterine ait alt boyutlarının ve toplam iletişim becerileri puanlarınının ortalamaları Tablo 4'de verilmiştir.

Tablo 4: İletişim Becerileri Alt Boyutları Puanları

\begin{tabular}{|c|c|c|c|}
\hline & Gözlem Sayısı & Ort. & Standart Sapma \\
\hline Zihinsel İletişim Becerileri (ZiB) & 224 & 3,9431 & 82994 \\
\hline Davranışsal i̇letişim Becerileri (DAB) & 224 & 4.0725 & 29546 \\
\hline Duygusal İletişim Becerileri (DUB) & 224 & 3.3994 & 94647 \\
\hline Genel İletişim Becerileri (GEB) & 224 & 3.8166 & 43232 \\
\hline
\end{tabular}

Tabloda yer alan sonuçlara göre anket kapsamındaki banka çalışanlarının iletişim becerileri alt boyutlarından "Davranışsal İletişim Becerileri (DAB)" boyutunun en yüksek skora sahip olduğu anlaşılmaktadır. Çalışmamızda iletişim becerileri alt boyutları için değerlendirme puanları yanı sıra "Genel İletişim Becerileri (GEB)" puanı da hesaplanmıştır. Ankete katılan banka çalışanlarının genel iletişim becerileri puanı 3,8166 olarak bulunmuştur.

Ankete katılan banka çalışanlarının iletişim becerileri envanterine ait alt boyutlarının ve genel iletişim becerileri puanlarınının cinsiyet değişkenine göre karşılaştırılmasına ilişkin yapılan T-Testi sonuçları Tablo 5 'de verilmiştir.

Tablo 5: Iletişim Becerileri Alt Boyutlarının ve Genel iletişim Becerileri Puanların Cinsiyet Değişkenine Göre Karşılaştırılmasına İlişkin T-Testi Sonuçları

\begin{tabular}{llrrrr}
\hline CINSIYET & & ZiB & DAB & DUB & \multicolumn{1}{c}{ GEB } \\
\hline \multirow{2}{*}{ KADIN } & Ortalama & 4,0743 & 3,9598 & 3,9179 & 3,9859 \\
& $\mathbf{N}$ & 83 & 83 & 83 & 83 \\
& Std. Sapma &, 30159 &, 65389 &, 77421 &, 32972 \\
\hline \multirow{2}{*}{ ERKEK } & Ortalama & 4,0715 & 3,9332 & 3,0941 & 3,7169 \\
& $\mathbf{N}$ & 141 & 141 & 141 & 141 \\
& Std. Sapma &, 29287 &, 92003 &, 90697 &, 45501 \\
\hline $\mathbf{T}$ & &, 068 &, 231 & 6,921 & 4,705 \\
\hline $\mathbf{P}$ & &, 946 &, 817 &, $000 * *$ &, $000 * *$ \\
\hline
\end{tabular}


Tablo 5'de "Duygusal illetişim Becerileri (DUB)" puanının kadınlarda 3,9179 erkeklerde ise 3,0941 olduğu ve p>0,01 önem düzeyinde istatistiksel anlamda farklılık gösterdiği görülmektedir. "Genel İletişim Becerileri (GEB)" puanının ise kadınlarda 3,9858 olduğu, erkeklerde 3,7169 olduğu ve p>0,01 önem düzeyinde istatistiksel anlamda farklılık gösterdiği görülmektedir. Bu durumda kadın banka çalışanlarının genel iletişim becerilerinin erkek çalışanlara göre daha olumlu görüldüğü söylenebilir.

İletişim becerileri envanteri alt boyutları arasındaki korelasyon analizi sonuçları Tablo 6'da verilmiştir.

Tablo 6: Iletişim Becerileri Alt Boyutları Arasındaki Korelasyonlar

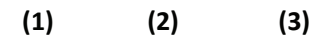

(1) Zihinsel İletişim Becerileri (ZiB)

(2) Davranışsal i̇letişim Becerileri (DAB)

, $204 * *$

(3) Duygusal ìletişim Becerileri (DUB)

, 002

$-080$

(4) Genel Iletişim Becerileri (GEB)

$, 707 * * \quad, 313 * * \quad, 670 * *$

$* * \mathrm{p}<0.01$

Analiz sonuçlarına göre; iletişim becerileri alt boyutlarından "Zihinsel iletişim Becerileri (ZiB)" ile "Davranışsal iletişim Becerileri (DAB)" ve "Genel İletişim Becerileri (GEB)" arasında $p<0.01$ anlamlılık düzeyinde pozitif ilişki elde edilmiştir. İletişim becerileri alt boyutlarından "Duygusal iletişim Becerileri (DUB)" ile iletişim becerilerinin diğer alt boyutları arasında bir ilişki tespit edilemezken, "Genel İletişim Becerileri (GEB)" ile $p<0.01$ anlamlılık düzeyinde pozitif ilişsi elde edilmiştir.

\section{SONUC}

Bu çalışmada Balıkesir ili Körfez bölgesinde (Edremit, Burhaniye, Gömeç, Ayvalık, Havran) faaliyet gösteren banka çalışanların iletişim becerileri düzeylerinin tespiti ve demografik faktörlere göre farklılık gösterip göstermediği incelenmiştir. Araştırma sonuçlarına göre banka çalışanlarının iletişim becerileri boyutlarından "Davranışsal illetişim Becerileri (DAB)" boyutunun en yüksek puana sahip olduğu, genel iletişim becerileri puanının ise 3,8166 olduğu görülmektedir. Literatürde, İletişim Becerileri Envanteri kullanılarak yapılan çalışmalarda, 5'li Likert tipi puanlama yapılarak her bir alt boyutun aldığı puanlar en düşük 15 ve en yüksek 75 olmak üzere farklı meslek grupları için iletişim becerileri puanları tespit edilmiştir. Bunlardan Toy (2007) tarafından yapılan araştırmada mühendislik ve hukuk fakülteleri öğrencilerinin zihinsel iletişim becerileri puanı 54,49, duygusal iletişim becerileri puanı 54,45, davranışsal iletişim becerileri puanı 56,33 ve genel iletişim becerileri GiB puanı da 165,27 olarak bulunmuştur. Gürşimşek vd. (2008) tarafından sınıf öğretmenliği ve okul öncesi öğretmenliği adaylarının iletişim becerileri puanları 146,53 olarak tespit edilmiştir. Acar (2009) tarafından yapılan araştırmada ise öğretmen adaylarının zihinsel iletişim becerileri puanı 53,10, duygusal iletişim becerileri puanı 48,01, davranışsal iletişim becerileri puanı 52,01 ve genel iletişim becerileri puanı ise 153,12 olarak bulunmuştur. Akyurt (2009) tarafından SHMYO öğrencilerinin iletişim becerileri düzeylerinin değerlendirildiği çalışmada, öğrencilerin davranışsal iletişim becerileri puan ortalamaları 36,64, zihinsel iletişim becerileri puan ortalamaları 42,15, duygusal iletişim becerileri ortalamaları 32,82 ve genel iletişim becerileri puan ortalamaları ise 111,62 olarak bulunmuştur. Çetinkaya (2011) Türkçe öğretmenliği adaylarının iletişim becerileri puanının 132 ile 210 arasında farklılaştığını ve katılımcıların iletişim becerilerine ilişkin görüşlerinin ortalamasının ise 177,94 olduğunu tespit etmiştir. Küçük (2011) tarafından yapılan diğer bir çalışmada ise müzik öğretmenliği adaylarının iletişim becerileri puan ortalaması 169,41 olarak bulunmuştur. Erigüç ve Eriş (2013) yaptıkları çalışmada ise SHMYO öğrencilerinin bilişsel iletişim becerileri puan ortalamalarını 56,80, duyuşsal iletişim becerileri puan ortalamalarını 52,63, davranışsal iletişim becerileri puan ortalamalarını 57,18, genel iletişim becerileri puan ortalamalarını ise 166,62 olarak bulmuşlardır. Erigüç vd., (2013) tarafından yapılan çalışmada ise Bilecik Şeyh Edebali Üniversitesi Osmaneli Meslek Yüksekokulu öğrencilerinin bilişsel iletişim becerileri puanı 55,14, duyuşsal iletişim becerileri puanı 53,41, davranışsal iletişim becerileri puanı 57,61 ve genel iletişim becerileri puanı ise 166,16 olarak hesaplanmıştır. Bu durumda, bu araştırmaya konu edilen banka çalışanlarının iletişim becerileri düzeylerinin, literatürde farklı meslek ve grupları için hesaplanmış iletişim puanlarından çoğunlukla daha yüksek olduğunu söylenebilir.

Araştırmada, iletişim becerileri alt boyutlarından "Duygusal iletişim Becerileri (DUB)" puanının kadınlarda 3,9179 erkeklerde ise 3,0941 olduğu ve p>0,01 önem düzeyinde istatistiksel anlamda farklılık gösterdiği tespit edilmiştir. "Genel İletişim Becerileri (GEB)" puanının ise kadınlarda 3,9858 olduğu, erkeklerde 3,7169 olduğu ve p>0,01 önem düzeyinde istatistiksel anlamda farklılık gösterdiği görülmektedir. Bu durumda kadın banka çalışanlarının genel iletişim becerileri puanının erkek çalışanlara göre daha yüksek olduğu belirlenmiştir. Toy (2007) tarafından yapılan araştırmada üniversite öğrencilerinin duygusal iletişim becerileri alt boyutunda cinsiyete göre anlamlı bir farklılık görülmezken, zihinsel, davranışsal ve genel iletişim becerilerinde kadın öğrenciler lehine anlamlı bir farklıık tespit edilmiştir. Acar tarafından (2009) öğretmen adaylarının iletişim becerilerinin ele alındığı çalışmada, öğretmen adaylarının cinsiyetlerine göre iletişim becerileri toplam 
puanları arasında anlamlı bir farklıık bulunmamış, ancak iletişim becerileri alt boyutlarından davranışsal iletişim becerileri alt boyutunda cinsiyete göre anlamlı bir farklılık bulunmuş ve erkek öğretmen adaylarının ortalamalarının daha yüksek olduğu tespit edilmiştir. Erigüç vd. (2013) tarafından yapılan çalışmada öğrencilerin cinsiyetlerine göre duyuşsal, davranışsal ve genel iletişim becerileri puanlarının farklılık gösterdiği görülmüş, kadın öğrencilerin duyuşsal, davranışsal ve genel iletişim becerileri düzeylerine ilişkin görüşlerinin erkek öğrencilerden daha olumlu olduğu tespit edilmiştir. İnsanlarla iletişimin yoğun olduğu tüm mesleklerde olduğu gibi bankacılık sektöründe de çalışanların iletişim becerileri örgüt içi çatışmanın yönetilmesini, iş gücü devir oranının azaltılmasını, motivasyonun yükseltilmesini, müşteri memmuniyetinin arttırılmasını sağlayacak ve böylece örgüt performansına olumlu etki yapacaktır. Örgüt çalışanlarının iletişim becerilerinin geliştirilmesine yönelik eğitim programlarının düzenlenmesi ve bunun örgüt kültürünün bir unsuru haline getirilmesi faydalı olacaktır. Uygulamada özellikle bankacılık sektöründe bu tür eğitimlerin çalışanlara verildiği bilinmekle olup bu durumun da banka çalışanlarının iletişim becerileri puanına olumlu katkı sağladığı düşünülmektedir. Araştırmamız Balıkesir ili Edremit Körfezi bölgesinde (Edremit, Burhaniye, Gömeç, Ayvalık, Havran) faaliyet gösteren bankalardaki çalışanlar üzerinde yapılmış olup, farklı sektörlerde çalışanların ve ülkemizin diğer bölgelerinde faaliyet gösteren banka çalışanları üzerinde de benzer araştırmaların yapılması gelecekteki araştırmacılara önerilmektedir.

\section{KAYNAKÇA}

ACAR, V. (2009). 'Öğretmen Adaylarının Iletişim Becerileri. Yüksek Lisans Tezi, Mehmet Akif Ersoy Üniversitesi Sosyal Bilimler Enstitüsü, Burdur.

AKGÜÇ, Ö. (1992). 100 Soruda Türkiye'de Bankacılık (Üçüncü Baskı). Gerçek Yayın Evi.

AKYURT, N. (2009). Sağlıkta Iletişim ve Marmara Üniversitesi Sağlık Hizmetleri Meslek Yüksekokulu Öğrencilerinin Iletişim Becerileri. Fırat Sağlık Hizmetleri Dergisi, 4, 11.

ALTUĞ, O. (2000), Banka Işslemleri Muhasebesi, Türkmen Kitabevi, Istanbul.

BAUER, R. K. (1989). An Evaluation of Communicative Skills as Enrichment Programs Taught in the Military Police Officer Basic Source. Dissertation Abstracts International Section a Humanities and Social Sciences 50(5-A) 1194.

BÜYÜKÖZTÜRK, S., KILIÇ ÇAKMAK, E., AKGÜN, Ö. E., KARADENIZ, S., \& DEMiREL, F. (2012). Bilimsel Araştırma Yöntemleri (18. Baski). Ankara: Pegem Akademi Yayimcilik.

CAN, H. (1999). Organizasyon ve Yönetim (5.baskı). Ankara: Siyasal Kitabevi.

ÇAM, S. (1999). Iletişim Becerileri Eğitimi Programının Öğretmen Adaylarının Ego Durumlarına ve Problem Çözme Becerisine Etkisi. Türk PDR Dergisi, 12,16-27.

ÇETINKAYA, Z. (2011). Türkçe Öğretmen Adaylarının Illetişim Becerilerine Illişkin Görüşlerinin Belirlenmesi. Kastamonu Eğitim Dergisi, 19-2, 567-576.

DICKSON, D. A. (1989). Interpersonal Communication in the Health Professions: A Focus on Training, Counseling Psychology Quartely, 2(3), 345-366.

DÖKMEN, Ü., (1994). Okuma Becerisi, Ilgisi ve Alışkanlığı Üzerine Psiko-Sosyal Bir Araştırma, M.E.B. Yayınları, No.2531, istanbul, s.10.

ERIGÜÇ, G., \& ERIŞ, H. (2013). Communication Skills of Students at Vocational Health High School: Harran University Sample. Electronic Journal of Social Science, Summer, 12(46), 232-254.

ERIGÜÇ, G., ŞENER, T. \& HÜSEYIN, E. (2013). Iletişim Becerilerinin Değerlendirilmesi: Bir Meslek Yüksekokulu Öğrencileri Örneği. Hacettepe Sağlık Idaresi Dergisi, 16(1).

ERSANLI, K., \& BALCI, S. (1998). Iletişim Becerileri Envanterinin geliştirilmesi: Geçerlik ve güvenirlik çalışması.[Examination the perception of problem-solving skills of university students whose irrational thoughts are different]. Turkish Psychological Counseling and Guidance Association, 22 (10), 7, 12.

EYÜPGiLLER, S. (2000), Bankalar Iç̧in Banka Işsletmeciliği Bilgisi, Banka ve Ticaret Hukuku Araştırma Enstitüsü, Ankara.

GÖKÇE, O., FIDAN, M. \& SUMMAK, E., (2001) Halkla ilişkiler Ders Notları, Selçuk Üniversitesi, iiBF Yayınları, Konya.

GÜRGEN, H., (1997). Örgütlerde Illetişim Kalitesi, İstanbul: Der Yayınları.

GÜRŞIMŞEK, I., VURAL, D. E., \& DEMIRSÖZ, E. S. (2008). Öğretmen Adaylarının Duygusal Zekâları Ile Iletişim Becerileri Arasındaki ilişki. Mehmet Akif Ersoy Üniversitesi Eğitim Fakültesi Dergisi, 8(16), 1-11.

KEENAN, F. \& BRADY, D. (2002). Carees, News Analysis How Soft-Touch Ceos Get Hard Results. Retreived March 25, From Business Week Online.

KORKUT, F. (2005). Yetişkinlere Yönelik Iletişim Becerileri Eğitimi. Hacettepe Üniversitesi Eğitim Fakültesi Dergisi, 28, $143-149$. 
KüÇÜK, D. P. (2012). Müzik Öğretmenliği Anabilim Dalı Öğrencilerinin Iletişim ve Problem Çözme Becerileri. Gazi Üniversitesi Gazi Eğitim Fakültesi Dergisi, 32(1).

OSKAY, Ünsal (2001), Iletişimin ABC'si, İstanbul: Der Yayınları.

SARAÇOĞLU, A.S., YENICE,N. \& KARASAKALOĞLU, N.(2009). Öğretmen Adaylarının Iletişim ve Problem Çözme Becerileri ile Okuma Ilgi ve Alışkanlıkları Arasındaki ilişki, Yüzüncü Yıl Üniversitesi, Eğitim Fakültesi Dergisi. Aralık 2009. Cilt:VI, Sayı:Il, 187-206

SELLICK, K. J. (1991). Nurses' Interpersonal Behaviors and the Development of Helping Skills. International Journal of Nursing Studies, 28(1), 3-11.

ŞENDOĞDU, A. (2006), Bankacılığa Giriş, Nobel Yayınları, Ankara.

TAYLOR, S. (2000). Strategies for Success: Polishing Your Personal Skills. Career World, 28(6), 20.

TOY, S. (2007). Mühendislik Ve Hukuk Fakülteleri Öğrencilerinin Iletişim Becerileri Açısından Karşılaştırılması ve Iletişim Becerileriyle Bazı Değişkenler Arasındaki Iliş̧kiler. Yüksek Lisans Tezi, Ankara Üniversitesi, Ankara.

UĞURLU, C,T. (2013). Öğretmenlerin Iletişim Becerisi ve Empatik Eğilim Davranışlarının Çocuk Sevme Düzeyleri Üzerine Etkisi, Pegem Eğitim ve Öğretim Dergisi, 3(2),51-61 